\title{
A Novel Micro Cold Atmospheric Plasma Device for Glioblastoma Both In Vitro and In Vivo
}

\author{
Zhitong Chen ${ }^{1}$, Hayk Simonyan ${ }^{2}$, Xiaoqian Cheng ${ }^{1,3}$, Eda Gjika ${ }^{1}$, Li Lin ${ }^{1}$, Jerome Canady ${ }^{3}$, \\ Jonathan H. Sherman ${ }^{4}$, Colin Young ${ }^{2, *}$ and Michael Keidar ${ }^{1, *}$ \\ 1 Department of Mechanical and Aerospace Engineering, The George Washington University, Washington, \\ DC 20052, USA; zhitongchen@gwu.edu (Z.C.); xiaoqian@gwmail.gwu.edu (X.C.); egjika@gwu.edu (E.G.); \\ lilin@email.gwu.edu (L.L.) \\ 2 Department of Pharmacology and Physiology, The George Washington University, Washington, DC 20052, \\ USA; hayksimonyan@email.gwu.edu \\ 3 Jerome Canady Research Institute for Advanced Biological and Technological Sciences, US Medical \\ innovation LLC, Takoma Park, MD 20912, USA; drjcanady@canadysurgicalgroup.com \\ 4 Department of Neurosurgery, The George Washington University, Washington, DC 20052, USA; \\ jsherman@mfa.gwu.edu \\ * $\quad$ Correspondence: colinyoung@gwu.edu (C.Y.); keidar@gwu.edu (M.K.); Tel.: +1-202-994-9575 (C.Y.); \\ +1-202-994-6929 (M.K.)
}

Academic Editor: Samuel C. Mok

Received: 10 March 2017; Accepted: 25 May 2017; Published: 30 May 2017

\begin{abstract}
Cold atmospheric plasma (CAP) treatment is a rapidly expanding and emerging technology for cancer treatment. Direct CAP jet irradiation is limited to the skin and it can also be invoked as a supplement therapy during surgery as it only causes cell death in the upper three to five cell layers. However, the current cannulas from which the plasma emanates are too large for intracranial applications. To enhance efficiency and expand the applicability of the CAP method for brain tumors and reduce the gas flow rate and size of the plasma jet, a novel micro-sized CAP device $(\mu \mathrm{CAP})$ was developed and employed to target glioblastoma tumors in the murine brain. Various plasma diagnostic techniques were applied to evaluate the physics of helium $\mu$ CAP such as electron density, discharge voltage, and optical emission spectroscopy (OES). The direct and indirect effects of $\mu C A P$ on glioblastoma (U87MG-RedFluc) cancer cells were investigated in vitro. The results indicate that $\mu \mathrm{CAP}$ generates short- and long-lived species and radicals (i.e., hydroxyl radical $(\bullet \mathrm{OH})$, hydrogen peroxide $\left(\mathrm{H}_{2} \mathrm{O}_{2}\right)$, and nitrite $\left(\mathrm{NO}_{2}{ }^{-}\right)$, etc.) with increasing tumor cell death in a dose-dependent manner. Translation of these findings to an in vivo setting demonstrates that intracranial $\mu \mathrm{CAP}$ is effective at preventing glioblastoma tumor growth in the mouse brain. The $\mu$ CAP device can be safely used in mice, resulting in suppression of tumor growth. These initial observations establish the $\mu \mathrm{CAP}$ device as a potentially useful ablative therapy tool in the treatment of glioblastoma.
\end{abstract}

Keywords: micro-sized plasma device; glioblastoma; reactive oxygen species; reactive nitrogen species; cancer therapy

\section{Introduction}

Plasma is an ionized gas consisting of positive/negative charges, radicals, neural atoms and ultraviolet (UV) photons, that is, a gaseous matter with quasi-neutral charges [1-3]. Atmospheric plasma at or near ambient temperature has led to a new field of plasma medicine [4,5], and cold atmospheric plasma (CAP) has attracted a lot of attentions due to its remarkable potential to affect biological processes [2,6]. In this context, the potential of CAP in diverse bio-medical applications has been explored, including disinfection, wound treatments, control of inflammation, blood coagulation, 
cancer therapy, and regenerative medicine [7-11]. The efficacy of CAP in the proposed applications relies on the synergistic action of the reactive oxygen species (ROS), reactive nitrogen species (RNS), free radicals, UV photons, charged particles, and electric fields [12-15]. A low dose of ROS and RNS was reported to induce cell proliferation as well as cell death, while a high dose of ROS/RNS can damage proteins, lipids, DNA, and induce apoptosis [16-19]. Some results also indicated that exposing cancer cells to CAP resulted in the production of free radicals that could cause apoptotic cell death [20]. Many studies of CAP for cancer therapy have indicated that CAP does not harm normal tissue when applied at the appropriate dosages [21-24]. Taken together, CAP therapy has been introduced as a cost effective, rapid and selective treatment modality for killing cancer cells.

CAP may be generated by a range of different plasma devices such as the plasma jet, dielectric barrier discharge, corona discharge, and gliding arc [25-28]. CAP-generated plasma can be directly applied to skin cancers. However, most cancers occur inside the body, therefore plasma irradiation is not practical due to the high voltage, the formation of discharge in the organ, gas delivery and plasma probe volume [29]. The biological effects of micro-sized plasma were studied in vitro and in vivo earlier [29-31]. However, these studies were not completely successful in carrying out CAP treatment at a specific position inside the body of animals. In this regard, glioblastoma is a highly malignant aggressive neoplasm of the primary central nervous system characterized by rapid growth, extensive angiogenesis, and resistance to all current therapies [32,33]. The major limitations of glioblastoma tumor treatment and eventual tumor recurrence are: (1) that the brain is susceptible to damage with conventional therapies; (2) tumor cells are very resistant to conventional therapies; (3) many drugs cannot cross the blood-brain barrier to act on brain tumors; and (4) the brain has a very limited capacity to repair itself [32,34]. Thus, it is necessary to develop a plasma device with a reduced gas flow rate and size, which can potentially be used in vivo by circumventing the problems listed above. Here, a new micro-sized CAP ( $\mu \mathrm{CAP}$ ) device employing helium gas was developed, and the effect of $\mu \mathrm{CAP}$ on glioblastoma both in vitro and in vivo was evaluated.

\section{Results}

\section{1. $\mu \mathrm{CAP}$ and Optical Spectrum}

Figure 1a illustrates the $\mu \mathrm{CAP}$ setup used in this work. Figure $1 \mathrm{~b}$ illustrates $\mu \mathrm{CAP}$ direct treatment in which the $\mu \mathrm{CAP}$ was used to treat culture medium containing glioblastoma cancer cells. Figure $1 \mathrm{c}$ shows $\mu \mathrm{CAP}$ indirect treatment in which the $\mu \mathrm{CAP}$ was used to first treat deionized (DI) water. After treatment, the DI water was transferred to culture medium containing cells (70 $\mu \mathrm{L}$ Dulbecco's Modified Eagle Medium (containing cells) $+30 \mu \mathrm{L}$ treated DI water, total $100 \mu \mathrm{L}$ ). The times for both direct and indirect treatment were $5,10,30,60$, and $120 \mathrm{~s}$. Figure $1 \mathrm{~d}$ shows the spectrum of the He $\mu \mathrm{CAP}$ with a flow rate of $0.1 \mathrm{~L} / \mathrm{min}$. The identification of the emission line and bands was performed mainly according to [35]. The peaks of $315 \mathrm{~nm}, 337 \mathrm{~nm}, 357 \mathrm{~nm}$, and $380 \mathrm{~nm}$ represent the photon emission intensity as the results of excited $N_{2}$ drops from the state $C^{3} \Pi_{u}$ to $B^{3} \Pi_{g}$ with different upper and lower vibration quantum numbers. The $281-\mathrm{nm}$ peak represents the photon emitted by excited NO drops from $\mathrm{A}^{2} \Sigma^{+}$to $X^{2} \Pi$ [35]. The helium bands were assigned between 500 and $750 \mathrm{~nm}$ as shown in Figure $1 \mathrm{~d}$. Species at a wavelength of $309 \mathrm{~nm}$ could be defined as $\mathrm{OH}$. Both He bands between $250 \mathrm{~nm}$ and $425 \mathrm{~nm}$ could be defined as ROS/RNS. The nitrogen and $\mathrm{OH}$ emission bands likely arise from the helium supply and ambient air. 


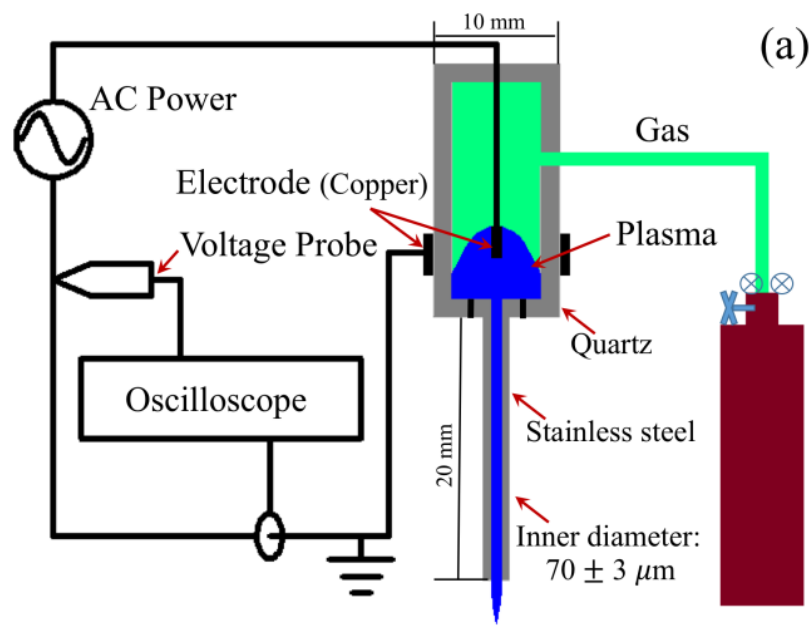

(b)
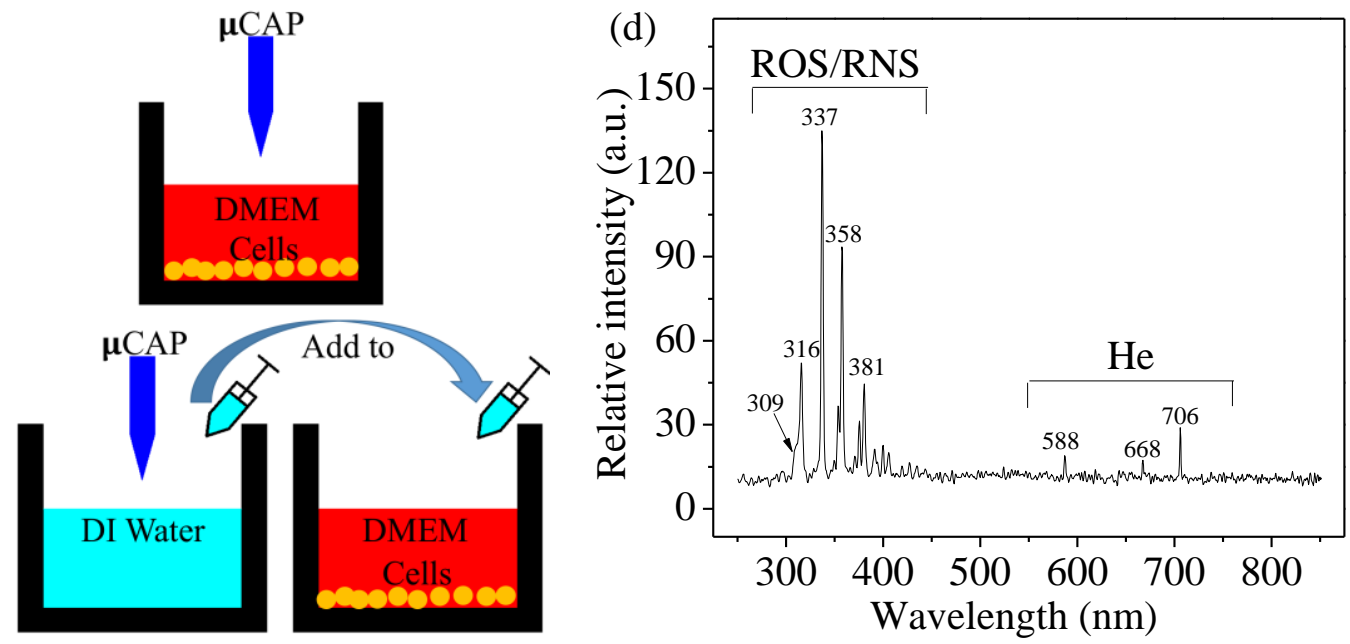

Figure 1. (a) Schematic representation of the micro-sized cold atmospheric plasma setup; (b) $\mu \mathrm{CAP}$ direct treatment: $\mu$ CAP was directly applied to cells in DMEM $(100 \mu \mathrm{L}) ;(\mathbf{c}) \mu \mathrm{CAP}$ indirect treatment: DI water was treated with $\mu$ CAP and then applied to cells in DMEM $(70 \mu \mathrm{L}$ DMEM $+30 \mu \mathrm{L}$ treated DI water); (d) Optical emission spectrum detected from the He $\mu$ CAP using UV-visible-NIR, in the 250-850 nm wavelength range. ROS: reactive oxygen species; RNS: reactive nitrogen species; CAP: cold atmospheric plasma; $\mu$ CAP: micro-sized CAP; DMEM: Dulbecco's Modified Eagle Medium; DI: Deionized; $\mu$ CAP: Micro-sized cold atmospheric plasma; AC: Alternating current.

\subsection{Electron Density of He $\mu \mathrm{CAP}$ Jet}

The experimental Rayleigh microwave scattering (RMS) system is shown in Figure 2a. The dependence of the output RMS signal on parameters of the scattering channel can be expressed as $U=A \sigma V$, where $A$ is the proportionality coefficient $\left(\mathrm{A}=263.8 \mathrm{~V} \Omega / \mathrm{cm}^{2}\right)$ and $V$ is the plasma volume. The volume of the plasma column was determined from intensified charged-coupled device (ICCD) images. $\sigma$ is plasma conductivity using the following expression: $\sigma=2.82 \times$ $10^{-4} n_{e} v_{m} /\left(\omega^{2}+v_{m}^{2}\right), \Omega^{-1} \mathrm{~cm}^{-1}$, where $v_{m}$ is the frequency of the electron-neutral collisions, $n_{e}$ is the plasma density, and $\omega$ is the angular frequency [36,37]. Combining these equations yields $n_{e}=\left(\left(\omega^{2}+v_{m}^{2}\right) U\right) /\left(\left(2.82 \times 10^{-4} A v_{m}\right) V\right)$. Therefore, we can calculate the total electron number in the plasma as $N_{e}=n_{e} V=U\left(\omega^{2}+v_{m}^{2}\right) /\left(2.82 \times 10^{-4} A v_{m}\right)$. The electron number of He $\mu \mathrm{CAP}$ is presented in Figure $2 b$, and the total electron number for one discharge period is $2.4 \times 10^{9}$. 
(a)
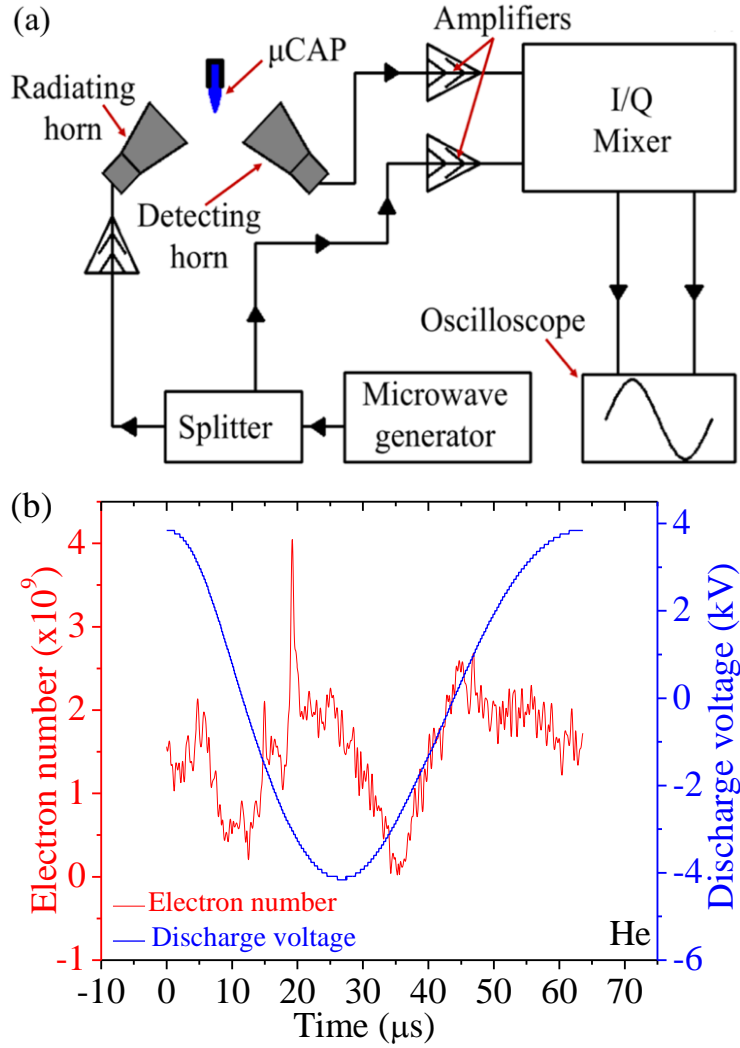

Figure 2. Schematics of the Rayleigh microwave scattering (RMS) experimental setup (a), as well as the electron number and discharge voltage of $\mathrm{He}(\mathbf{b})$. He: Helium.

\subsection{Detection of RNS Generated by $\mu C A P$}

$\mu$ CAP treatment of DI water and Dulbecco's Modified Eagle Medium (DMEM) were performed to induce changes in the concentration of ROS and RNS as a function of the treatment time. Indeed, as shown in Figure 3, the $\mathrm{NO}_{2}{ }^{-}$concentration in He $\mu$ CAP-treated DI water and DMEM increases with treatment duration. The $\mathrm{NO}_{2}{ }^{-}$mainly originates as $\mathrm{NO}\left(\mathrm{N}_{2}+\mathrm{e} \rightarrow 2 \mathrm{~N}+\mathrm{e}, \mathrm{N}+\mathrm{O}_{2} \rightarrow \mathrm{NO}+\mathrm{O}\right.$, $4 \mathrm{NO}+\mathrm{O}_{2}+2 \mathrm{H}_{2} \mathrm{O} \rightarrow 4 \mathrm{NO}_{2}{ }^{-}+4 \mathrm{H}^{+}$) [38-40], while most of $\mathrm{NO}$ is formed in the gas phase during the afterglow a few milliseconds after the discharge pulse. The $\mathrm{NO}_{2}{ }^{-}$concentration in DMEM treated with He $\mu \mathrm{CAP}$ is higher than that in DI water $(p<0.05$ for all treatment times). On the other hand, DMEM comprises over 30 components such inorganic salts, amino acids and vitamins, while the effect of plasma irradiation on these compounds is still unknown. Plasma might react with amino acids to form $\mathrm{NO}_{2}{ }^{-}$, which provides a possible explanation for higher $\mathrm{NO}_{2}{ }^{-}$concentration in DMEM than in DI water. Plasma-activated media produces a lot of species, including $\mathrm{NO}_{3}{ }^{-}$. In our previous study, the $\mathrm{Ph}$ range of plasma solutions was around 5.0 to 6.0 [16]. On the other hand, different concentrations of $\mathrm{H}_{2} \mathrm{O}_{2}$ show a Ph range from 4.5 to 6.2. Therefore, Ph of Mcap should be between 4.5 and 6.0. 

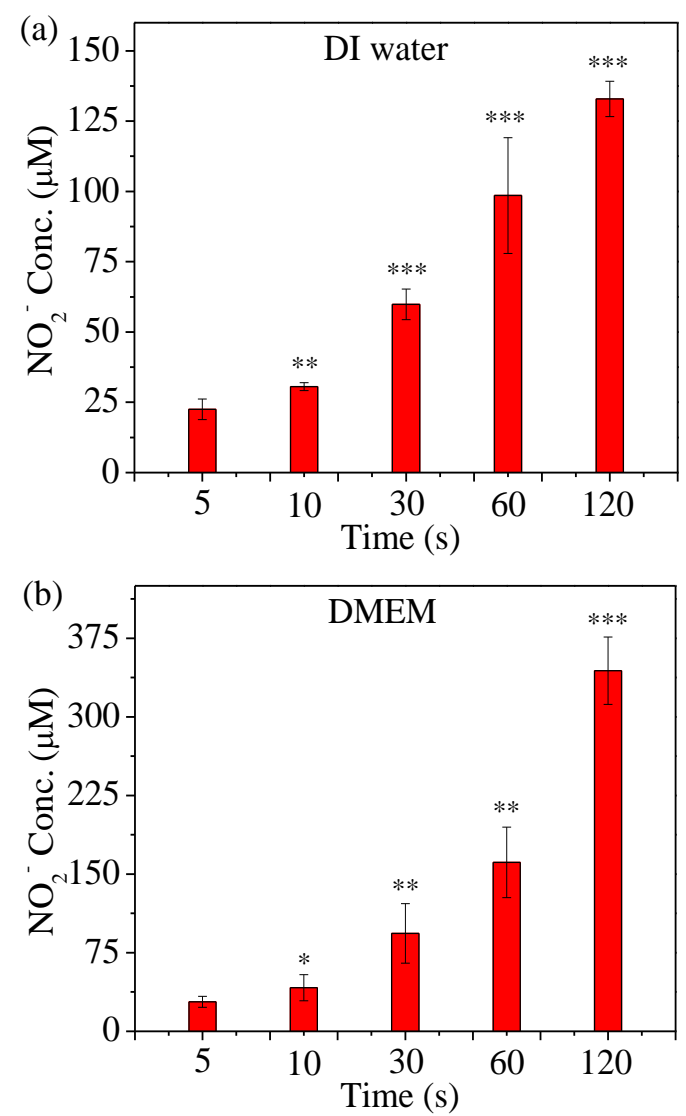

Figure 3. RNS concentration in He $\mu$ CAP-treated DI water (a) and DMEM (b). Student t-test was performed, and the statistical significance compared to $\mu \mathrm{CAP} 5 \mathrm{~s}$ treatment is indicated as * $p<0.05$, ** $p<0.01,{ }^{* * *} p<0.001 .(n=3)$.

\subsection{Assess Relative Concentration of Hydroxyl Radical}

Methylene blue $(\mathrm{MB})$ was used to assess the relative concentration of hydroxyl radicals $(\bullet \mathrm{OH})$. It is known that $\mathrm{MB}$ reacts with $\bullet \mathrm{OH}$ aqueous solutions, leading to a visible color change [41]. As shown in Figure 4, the relative MB concentration decreases with treatment time of $\mathrm{He} \mu \mathrm{CAP}$. The relative $\mathrm{MB}$ concentration decreases by $9.3 \%$ after He $\mu \mathrm{CAP}$-treated DI water for $120 \mathrm{~s}$. While this change is significant, He $\mu \mathrm{CAP}$-treated DMEM showed a stronger degradation action $(14.7 \%)$, suggesting that more short-living reactive species are generated in DMEM. Plasma reacting with DMEM might form a new product that reacts with methylene blue, which may explain why He Mcap-treated DMEM showed a stronger degradation action than DI water. Overall, these findings demonstrate that there is an increase in the relative concentration of $\bullet \mathrm{OH}$ as a function of $\mu \mathrm{CAP}$ treatment time.

\subsection{Detection of ROS Generated by $\mu C A P$}

Figure 5 shows the ROS concentration dependence on treatment time in He $\mu \mathrm{CAP}$-treated DI water and DMEM. $\mathrm{H}_{2} \mathrm{O}_{2}$ generation might be attributed to the high electron density and energy of the plasma $\left(\mathrm{He} \rightarrow \mathrm{He}^{+}+\mathrm{e}, \mathrm{He}^{+}+\mathrm{H}_{2} \mathrm{O} \rightarrow \mathrm{H}_{2} \mathrm{O}^{+}+\mathrm{He}, \mathrm{H}_{2} \mathrm{O}^{+}+\mathrm{H}_{2} \mathrm{O} \rightarrow \mathrm{H}_{3} \mathrm{O}^{+}+\bullet \mathrm{OH} ; \mathrm{He}+\mathrm{e} \rightarrow\right.$ $\mathrm{He}^{*}+\mathrm{e}, \mathrm{He}{ }^{*}+\mathrm{H}_{2} \mathrm{O} \rightarrow \mathrm{He}+\bullet \mathrm{OH}+\mathrm{H} \cdot ; \mathrm{H}_{2} \mathrm{O}+\mathrm{e} \rightarrow \mathrm{H}_{2} \mathrm{O}^{*}+\mathrm{e}, \mathrm{H}_{2} \mathrm{O} * \rightarrow \bullet \mathrm{OH}+\mathrm{H} \cdot ; \bullet \mathrm{OH}+\bullet \mathrm{OH}$ $\left.\rightarrow \mathrm{H}_{2} \mathrm{O}_{2}\right)[42,43]$. The $\mathrm{H}_{2} \mathrm{O}_{2}$ concentration increases with treatment duration for both DI water and DMEM, although the concentration of $\mathrm{H}_{2} \mathrm{O}_{2}$ generated in DI water is higher than DMEM. 

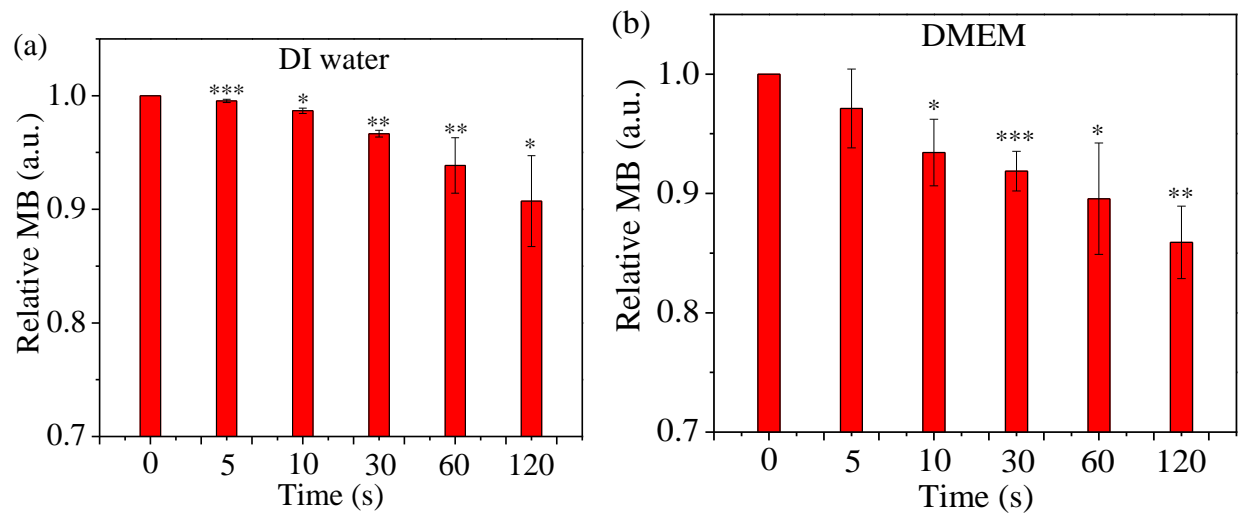

Figure 4. Relative methylene blue (MB) concentration for assessing the concentration of hydroxyl free radicals in He $\mu$ CAP-treated DI water (a) and DMEM (b). Student $t$-test was performed, and the statistical significance compared to MB without $\mu$ CAP treatment $(0 \mathrm{~s})$ is indicated as * $p<0.05$, ** $p<0.01,{ }^{* * *} p<0.001 .(n=3)$.
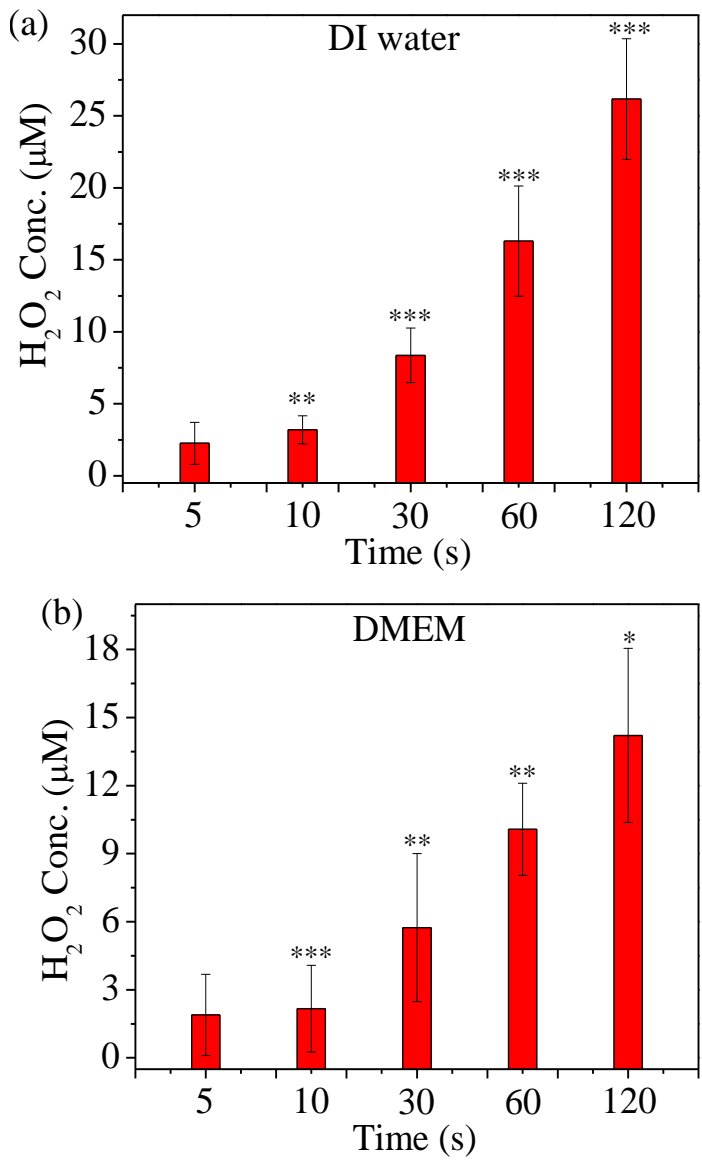

Figure 5. $\mathrm{H}_{2} \mathrm{O}_{2}$ concentration in $\mu$ CAP-treated DI water (a) and DMEM (b). Student $t$-test was performed, and the statistical significance compared to $\mu \mathrm{CAP} 5$ second treatment is indicated as ${ }^{*} p<0.05,{ }^{* *} p<0.01,{ }^{* * *} p<0.001 .(n=3)$.

\subsection{Cell Viability Follow In Vitro $\mu$ CAP Treatment Duration}

Figure 6a shows the cell viability of the glioblastoma cancer cells treated with He $\mu \mathrm{CAP}$ indirect treatment after 24 and $48 \mathrm{~h}$. The cell viability after $24 \mathrm{~h}$ incubation (normalized by DMEM control) decreased by approximately $14.2 \%, 19.9 \%, 25.4 \%, 29.0 \%, 34.7 \%$, and $39.2 \%$, according to $0,5,10,30,60$, 
and $120 \mathrm{~s}$ treatment durations, respectively. After $48 \mathrm{~h}$ of incubation, the cell viability decreased by approximately $18.3 \%, 35.6 \%, 34.8 \%, 41.1 \%, 54.7 \%$, and $51.4 \%$, for $0,5,10,30,60$, and 120 s treatment durations, respectively. Figure $6 \mathrm{~b}$ shows the cell viability of glioblastoma cancer cells after 24 and $48 \mathrm{~h}$ incubation with He $\mu \mathrm{CAP}$ direct treatment (treat $100 \mu \mathrm{L}$ media containing cells) for $0,5,10,30,60$, and $120 \mathrm{~s}$ duration. The cell viability of the glioblastoma cancer cells after 24-h incubation (normalized by control) decreased by approximately $15.4 \%, 27.1 \%, 28.9 \%, 44.1 \%$, and $65.1 \%$, according to 5, 10, 30, 60 , and 120 s treatment durations, respectively. Similar dose-dependent (i.e., increase treatment time) decreases in cell viability were found with 48 -h incubation.
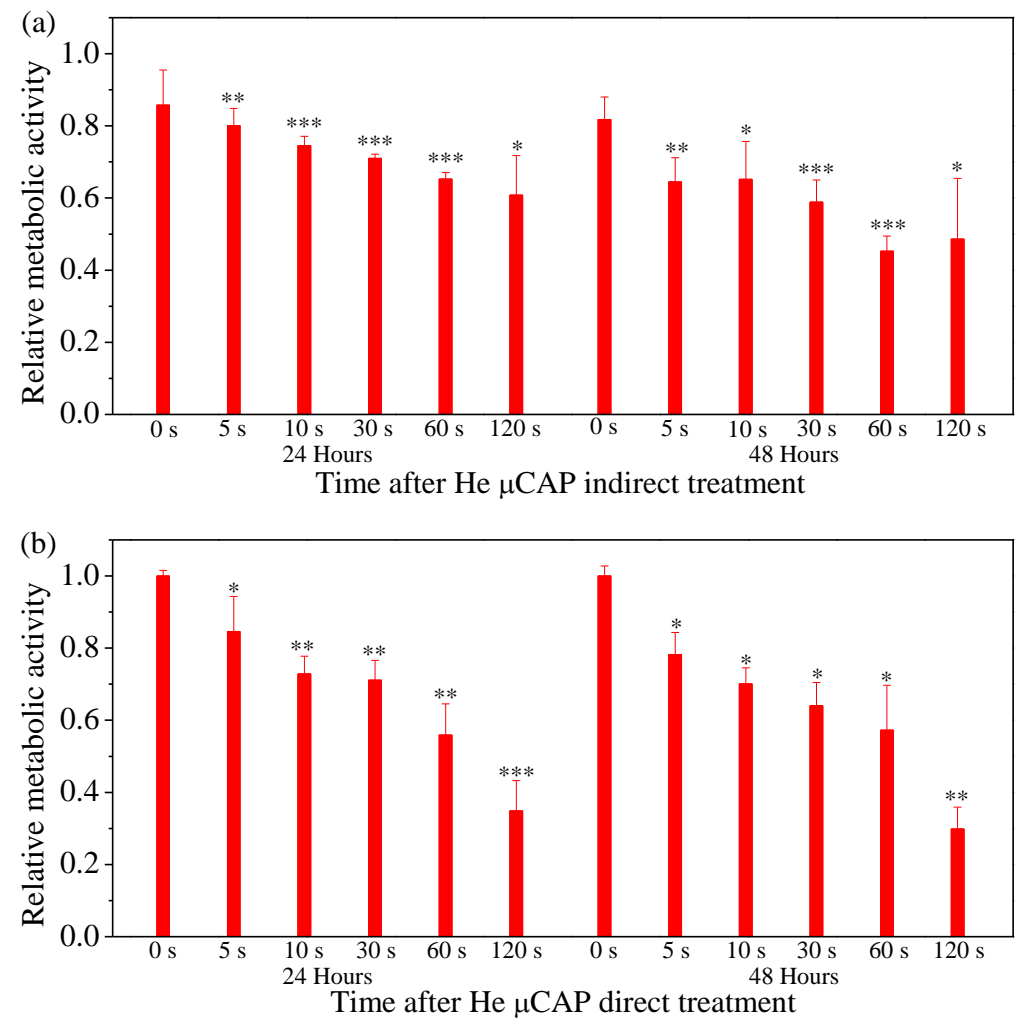

Figure 6. Cell viability of U87MG after 24 and $48 \mathrm{~h}$ of incubation with He $\mu$ CAP indirect treatment (a) and direct treatment (b) for 0,5,10, 30, 60, and $120 \mathrm{~s}$. The ratios of surviving cells for each cell line were calculated relative to controls $(0 \mathrm{~s})$ in DMEM. Student $t$-test was performed, and the statistical significance compared to cells present in $\operatorname{DMEM}(0 \mathrm{~s})$ is indicated as ${ }^{*} p<0.05,{ }^{* *} p<0.01,{ }^{* * *} p<0.001$. $(n=3)$.

\subsection{In Vivo Targeting of Glioblastoma with $\mu C A P$}

In order to determine the effect of the novel plasma device effect on glioblastoma in vivo, we directly applied He $\mu$ CAP for $15 \mathrm{~s}$ to glioblastoma tumors in the brain of living mice via an implanted endoscopic tube as shown in Figure 7a. Using in vivo bioluminescence imaging (Figure 7b), the tumor volume in a control animal (helium only) increased nearly $600 \%$ over the course of two days, whereas He $\mu$ CAP-treated tumor volume decreased approximately 50\% compared with baseline levels (Figure 7c). In the control animals, there is a clear increase in tumor volume over the 2-day period. In contrast, He $\mu \mathrm{CAP}$-treated animals fell below baseline values. These striking findings demonstrate the potential of $\mu \mathrm{CAP}$ to inhibit glioblastoma tumor growth in vivo. 
(a)

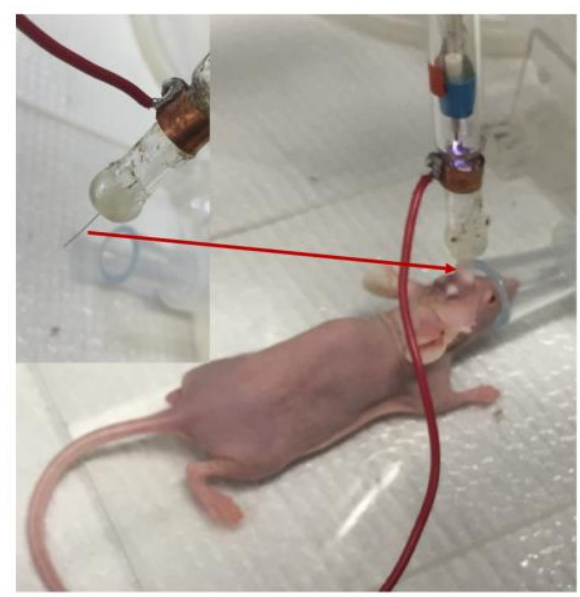

(b)

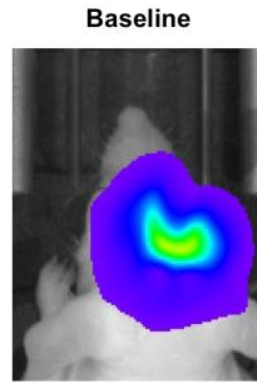

24 Hours
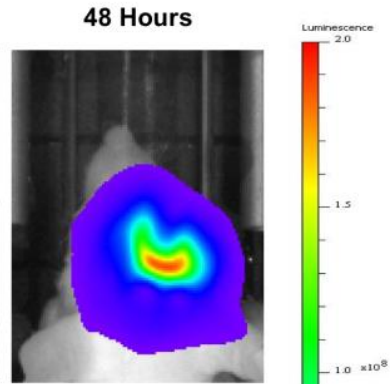

He $\mu$ CAP
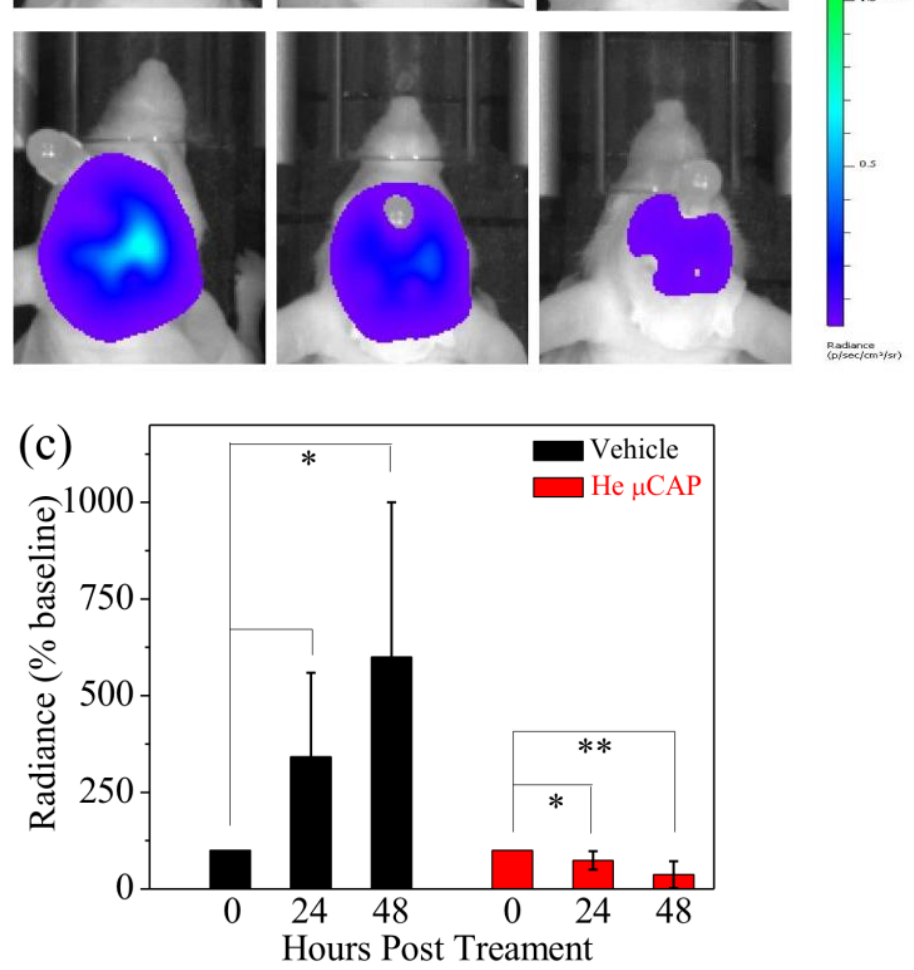

Figure 7. In vivo targeting of glioblastoma tumor with He $\mu$ CAP. (a) Photograph of a new $\mu$ CAP device for plasma delivery through an intracranial endoscopic tube to target glioblastoma tumors in the mouse brain; (b) Representative in vivo bioluminescence images illustrating glioblastoma tumor volume (i.e., light emission or radiance) at baseline and 2 days following He $\mu$ CAP or vehicle (helium) treatment. Areas of high photon emission are shown in red and low are shown in blue; (c) Group summary data ( $n=3$ /group) indicates that the tumor volume in control aggressively increased following treatment, whereas He $\mu \mathrm{CAP}$ delivery maintained tumor volume below basal levels. 


\section{Discussion}

CAP has received considerable attention for its potential biomedical applications. Emerging fields of application of CAP include wound healing, sterilization of infected tissue, inactivation of microorganisms, tooth bleaching, blood coagulation, skin regeneration, and cancer therapy. This has been collectively termed 'plasma medicine'. Both direct and indirect applications of CAP have been shown to be effective for treating various cancer cells in vitro and in vivo [11]. However, as discussed above, the treatment of tumors deep within the body has been hampered by the limitations of CAP delivery tools. Thus, we aimed to develop and study how application of a novel He $\mu$ CAP device could induce high cell death both in vitro and in vivo.

Treating culture media containing cells (direct treatment) was compared to treating DI water and removing it to culture media containing cells (indirect treatment). Our findings suggest that both $\mathrm{He}$ $\mu \mathrm{CAP}$ direct/indirect treatment could induce high cell death in glioblastoma cancer cells (Figure 6), although in general direct treatment was more effective than indirect treatment. Plasma contains the energy ions, free radicals, reactive species, UV radiation, and the transient electric fields inherent with plasma delivery, which interact with the cells and other living organisms. In many cases, it has been reported that plasma-induced apoptosis in cancer cells had no adverse effect on the normal cells when administered at the comparable dosage provided to cancer cells $[11,44,45]$. The absorption cross-section of ROS in the UV spectral range $(10-400 \mathrm{~nm})$ is relatively small [46], and the species lines between 300 and 350 are still not clearly determined. Radicals and electrons generated during plasma formation can be either short-lived or long-lived. These radicals or electrons reach a solution and form many complex reactions, which result in the formation of other short- and long-lived radicals or species. Short-lived radicals or species include superoxide $\left(\mathrm{O}_{2}{ }^{-}\right)$, nitrite $(\mathrm{NO})$, atomic oxygen $(\mathrm{O})$, ozone $\left(\mathrm{O}_{3}\right)$, hydroxyl radical $(\bullet \mathrm{OH})$, singlet delta oxygen $\left(\mathrm{SOD}, \mathrm{O}_{2}\left({ }^{1} \Delta g\right)\right)$, and peroxynitrite $\left(\mathrm{ONOO}^{-}\right)$, etc. $[47,48]$. Long-lived species include hydrogen peroxide $\left(\mathrm{H}_{2} \mathrm{O}_{2}\right)$ and nitrite $\left(\mathrm{NO}_{2}{ }^{-}\right)$[48].

In the case of indirect treatment $\mu \mathrm{CAP}$ (treatment of DI water and transfer to cells in a culture medium), one can argue that the primary effects are associated with long-lived species $\left(\mathrm{H}_{2} \mathrm{O}_{2}\right.$ and $\mathrm{NO}_{2}{ }^{-}$). RNS are known to induce cell death via DNA damage, while ROS can induce cell death by apoptosis and necrosis [49,50]. When $\mathrm{He}$ is used as a carrier gas, the concentration of $\mathrm{H}_{2} \mathrm{O}_{2}$ and $\mathrm{NO}_{2}{ }^{-}$in DI water rises with time (Figures 3 and 5). Analyzing cell viability, one can see that $\mathrm{He}$ $\mu \mathrm{CAP}$ has a strong effect on glioblastoma (U87MG) cancer cells. The $\mu \mathrm{CAP}$-generated $\mathrm{H}_{2} \mathrm{O}_{2}$ and $\mathrm{NO}_{2}{ }^{-}$concentration increase with treatment time, in line with the linear increase in cancer cell killing efficiency. However, there might be additional antitumor pathways related to $\mathrm{H}_{2} \mathrm{O}_{2}$ and $\mathrm{NO}_{2}{ }^{-}$. For example, $\mathrm{H}_{2} \mathrm{O}_{2}$ and $\mathrm{NO}_{2}{ }^{-}$are believed to generate peroxynitrite $\left(\mathrm{H}_{2} \mathrm{O}_{2}+2 \mathrm{NO}_{2}{ }^{-} \rightarrow 2 \mathrm{HONOO}^{-}\right)$ which is known to be toxic to cells [51]. $\mathrm{HONOO}^{-}$is stable at basic $\mathrm{pH}$ (DI water $<6$ ) or otherwise it immediately decomposes into $\mathrm{NO}_{3}{ }^{-}$. However, $\mathrm{HONOO}^{-}$may be difficult to generate in media because media is buffered and only slightly basic $(\mathrm{pH}>7)$ [52]. On the other hand, aquaporins (AQPs) play a critical role in facilitating the passive diffusion of $\mathrm{H}_{2} \mathrm{O}_{2}$, especially AQP8 [45,53-55]. Not all AQPs can transport $\mathrm{H}_{2} \mathrm{O}_{2}$, and AQPs show various transportation degrees of $\mathrm{H}_{2} \mathrm{O}_{2}$ in different types of human tumors. AQP1, 4, 8, and 9 are highly expressed in glioblastoma cell lines [45,56]. Thus, the distinct expression pattern of AQP8 in glioblastoma might be responsible for cancer cells being sensitive to high $\mathrm{H}_{2} \mathrm{O}_{2}$ concentrations.

The effect of both short- and long-lived species or radicals is plausible when considering $\mu \mathrm{CAP}$ direct-treated glioblastoma cancer cells (in vitro, Figure 6) and tumors in the mouse brain (in vivo, Figure 7). Of note, DMEM comprises over 30 components such as inorganic salts, amino acids and vitamins and the effect of plasma irradiation on these compounds is still unknown. Similarly, the effect of plasma irradiation in murine brain is also unknown. Therefore, unknown reactive species or radicals could be generated during the irradiation of DMEM and during in vivo application. Shortand long-lived species or radicals in DMEM and mice brain containing $\bullet \mathrm{OH}, \mathrm{NO}, \mathrm{O}_{2}{ }^{-}, \mathrm{O}_{2} \mathrm{O}_{3}, \mathrm{O}_{2}$ $\left({ }^{1} \Delta g\right), \mathrm{ONOO}^{-}, \mathrm{H}_{2} \mathrm{O}_{2}$ and $\mathrm{NO}_{2}{ }^{-}$are prominent components of antitumor plasma action [57]. The relative concentration of $\bullet \mathrm{OH}$ in DMEM treated by $\mathrm{He} \mu \mathrm{CAP}$ increases with treatment time (Figure 4). 
The color change of methylene blue shows the presence of $\mathrm{OH}$ radicals via immediate and distinct bleaching of methylene blue dye (qualitatively analysis) [41]. $\bullet \mathrm{OH}$-derived amino acid peroxides can contribute to cell injury because $\bullet \mathrm{OH}$ itself and protein (amino acid) peroxides are able to react with DNA, thereby inducing various forms of damage [58,59]. When He $\mu$ CAP activates DMEM, the concentration of both $\mathrm{H}_{2} \mathrm{O}_{2}$ and $\mathrm{NO}_{2}{ }^{-}$rises with treatment time (Figures 3 and 5), and synergism of $\mathrm{H}_{2} \mathrm{O}_{2}$ and $\mathrm{NO}_{2}{ }^{-}$mentioned above might be an important factor. CAP also produces significant amount of ozone $\left(\mathrm{O}_{3}\right)$, which is known to have strongly aggressive effect on cells [60]. Ozone has a role in the formation of biologically active ROS and RNS in aqueous media, which may be responsible for cell death [61,62]. Atomic oxygen $(\mathrm{O})$ (including the ground state and all the excited states) is believed to have a significant effect on cells $[63,64]$. Superoxide $\left(\mathrm{O}_{2}{ }^{-}\right)$generated by plasma can activate mitochondrial-mediated apoptosis by changing mitochondrial membrane potential and simultaneously up-regulates pro-apoptotic genes and down-regulates anti-apoptotic genes for activation of caspases resulting in cell death [65]. Singlet delta oxygen $\mathrm{O}_{2}\left({ }^{1} \Delta g\right)$ is another important ROS with the excitation energy of $0.98 \mathrm{eV}$. Highly reactive molecule $\mathrm{O}_{2}\left({ }^{1} \Delta g\right)$ not only produces oxidative damage in many biological targets but is also a primary active species in the selective killing of tumor cells in the emerging cancer therapy [66,67]. Moreover, nitrite $\left(\mathrm{NO}_{2}{ }^{-}\right)$and superoxide $\left(\mathrm{O}_{2}{ }^{-}\right)$can easily form $\mathrm{ONOO}^{-}$once they collide [68]. $\mathrm{ONOO}^{-}$is a powerful oxidant and nitrating agent, which is known to be highly damaging to tumor cells [69]. Overall, the above results and discussion indicate that both direct and indirect routes of delivering CAP might be useful and should be considered in a clinical medical application. A further understanding of the precise underlying mechanisms will allow for determination of the "best" combination when used as a treatment strategy.

\section{Materials and Methods}

\subsection{Experimental Device Configuration}

In Figure 1a, the $\mu \mathrm{CAP}$ device consists of a two-electrode (copper) assembly with a central powered electrode and a grounded outer electrode wrapped around the outside of a quartz tube $(10 \mathrm{~mm})$. The electrodes were connected to the secondary output of a high voltage transformer. The peak-peak voltage was about $8 \mathrm{kV}$ and the frequency of the discharge was around $15 \mathrm{kHz}$. The secondary output of the high voltage transformer was connected to the first input. The power of the first input is around 5 watts. At the end of a quartz tube, a $70 \pm 3 \mu \mathrm{m}$ inner diameter capillary tube (stainless steel) with a 20-mm length was attached and insulated by epoxy. The feeding gas for this study was industrial purity helium, which was injected into the quartz tube with a $0.1 \mathrm{~L} / \mathrm{min}$ gas flow rate.

\subsection{Optical Emission Spectroscopy (OES) Spectra Measurement}

UV-visible-NIR, with a range of wavelength $200-850 \mathrm{~nm}$, was investigated on plasma to detect various RNS and ROS (nitrogen $\left[\mathrm{N}_{2}\right]$, nitric oxide $[-\mathrm{NO}]$, nitrogen cation $\left[\mathrm{N}^{+2}\right]$, atomic oxygen $[\mathrm{O}]$, and hydroxyl radicals $[-\mathrm{OH}])$. The spectrometer and detection probe were purchased from Stellar Net Inc. (Tampa, FL, USA). The optical probe was placed at a distance of $1.0 \mathrm{~cm}$ in front of the plasma jet nozzle. Data were collected with an integration time of $100 \mathrm{~ms}$.

\subsection{A Rayleigh Microwave Scattering System (RMS) for Electron Number Measurement}

The experimental RMS system is schematically presented in Figure 2a. Two microwave horns were used for radiation and detection of microwave signal. Microwave radiation linearly polarized was scattered on the collinearly-oriented plasma channel and the scattered signal was then measured. The detection of the scattered signal was accomplished using a homodyne scheme by means of an $I / Q$ mixer, providing in-phase $(I)$ and quadrature $(Q)$ outputs. For the entire range of scattered signals, the amplifiers and mixer were operated in linear mode. The total amplitude of the scattered microwave signal was determined by: $U=\sqrt{I^{2}+Q^{2}}$. 


\subsection{Cell Culture}

Human glioblastoma cancer cells (U87MG, Perkin Elmer, Waltham, MA, USA) were cultured in Dulbecco's Modified Eagle Medium (DMEM, Life Technologies, Washington, WA, USA) supplemented with 10\% (v/v) fetal bovine serum (Atlantic Biologicals, Frederick, MD, USA) and 1\% (v/v) penicillin and streptomycin (Life Technologies). Cultures were maintained at $37^{\circ} \mathrm{C}$ in a humidified incubator containing $5 \%(\mathrm{v} / \mathrm{v}) \mathrm{CO}_{2}$.

\subsection{Determination of $\mathrm{H}_{2} \mathrm{O}_{2}$ Concentration}

A fluorimetric hydrogen peroxide assay Kit (Sigma-Aldrich, St. Louis, MO, USA) was used for measuring the amount of $\mathrm{H}_{2} \mathrm{O}_{2}$, according to the manufacturer's protocol. Briefly, $50 \mu \mathrm{L}$ of standard curve, control, and experimental samples were added to 96-well flat-bottom black plates, and then $50 \mu \mathrm{L}$ of Master Mix was added to each of well. The plates were incubated for $20 \mathrm{~min}$ at room temperature protected from light and fluorescence was measured by a Synergy H1 Hybrid Multi-Mode Microplate Reader at Ex/Em: 540/590 nm.

\subsection{Determination of $\mathrm{NO}_{2}{ }^{-}$Concentration}

RNS levels were determined by using a Griess Reagent System (Promega Corporation, Madison, WI, USA) according to the instructions provided by the manufacturer. Briefly, $50 \mu \mathrm{L}$ of samples and $50 \mu \mathrm{L}$ of the provided sulfanilamide solution were added to 96-well flat-bottom plates and incubated for 5-10 min at room temperature. Subsequently, $50 \mu \mathrm{L}$ of the NED solution was added to each well and incubated at room temperature for $5-10 \mathrm{~min}$. The absorbance was measured at $540 \mathrm{~nm}$ by a Synergy H1 Hybrid Multi-Mode Microplate Reader.

\section{7. $\bullet$ OH Accumulation in a Methylene Blue (MB) Solution}

An MB solution was prepared by dissolving MB power in DI water and DMEM. MB solutions $(100 \mu \mathrm{L}$ per well, $0.01 \mathrm{~g} / \mathrm{L})$ in a 96-well flat-bottom black plate were treated by He $\mu \mathrm{CAP}$ for 5,10 , 30,60 , and $120 \mathrm{~s}$. The gap between the outlet of $\mu \mathrm{CAP}$ and the surface of the samples was around $3 \mathrm{~mm}$. As a control, two untreated MB solutions in triplicate were transferred to a 96-well flat-bottom black plate. The color change of methylene blue shows the presence of $\mathrm{OH}$ radicals via immediate and distinct bleaching of methylene blue dye (qualitatively analysis). Color change of MB solution was measured as the absorbance at $664 \mathrm{~nm}$ by a Synergy H1 Hybrid Multi-Mode Microplate Reader.

\subsection{Cell Viability Following $\mu C A P$ Indirect Treatment In Vitro}

U87 cells were plated in 96-well flat-bottom microplates at a density of 3000 cells per well in $70 \mu \mathrm{L}$ of complete culture medium. Cells were incubated for $24 \mathrm{~h}$ to ensure proper cell adherence and stability. On day 2, $30 \mu \mathrm{L}$ of DI water was treated by He $\mu \mathrm{CAP}$ for $0,5,10,30,60$, and $120 \mathrm{~s}$, and was added to cells. Cells were further incubated at $37^{\circ} \mathrm{C}$ for 24 and $48 \mathrm{~h}$. The cell viability of the glioblastoma cancer cells was measured for each incubation time point with a 3-(4, 5-dimethylthiazol-2-yl)-2,5-diphenyltetrazolium bromide (MTT) assay. A volume of $100 \mu \mathrm{L}$ MTT solution (Sigma-Aldrich) was added to each well followed by a 3-h incubation. The MTT solution was discarded and $100 \mu \mathrm{L}$ per well of MTT solvent $(0.4 \%(\mathrm{v} / \mathrm{v}) \mathrm{HCl}$ in anhydrous isopropanol) was added to the wells. The absorbance of the purple solution was recorded at $570 \mathrm{~nm}$ with a Synergy H1 Hybrid Multi-Mode Microplate Reader.

\subsection{Cell Viability Following $\mu C A P$ Direct Treatment In Vitro}

U87 cells were plated in 96-well flat-bottom microplates at a density of 3000 cells per well in $100 \mu \mathrm{L}$ of complete culture medium. Cells were incubated for $24 \mathrm{~h}$ to ensure proper cell adherence and stability. On day 2, the cells were treated by He $\mu \mathrm{CAP}$ for $0,5,10,30,60$, and $120 \mathrm{~s}$. Cells were further incubated at $37^{\circ} \mathrm{C}$ for 24 and $48 \mathrm{~h}$. An MTT assay was used to assess cell viability as described above. 


\subsection{In Vivo Application of $\mu \mathrm{CAP}$ to Target Intracranial Glioblastoma}

All animal protocols were approved by the George Washington University Institutional Animal Care and Use Committee. Eight-week-old female athymic nude mice (Charles River, $\mathrm{NU}(\mathrm{NCr})-F_{0 x n} 1^{\mathrm{nu}}$ ) were anesthetized intraperitoneally (i.p.) (Ketamine $(100 \mathrm{mg} / \mathrm{kg})$ mixed with Xylazine $(10 \mathrm{mg} / \mathrm{kg})$ ) and placed in a stereotaxic frame. The surface of the skull was visualized with a dissecting microscope and horizontally leveled between bregma and lambda. A small hole was drilled at the desired location. U87MG-RedFluc cells (Perkin Elmer), containing a red-shifted firefly luciferase that allows for in vivo monitoring of tumor growth via light emission, were resuspended in DMEM at a concentration of $5 \times 10^{5}$ cell $/ \mu \mathrm{L}$ and injected into the frontal lobe at the following coordinates (relative to Bregma) using a Hamilton syringe: $2.2 \mathrm{~mm}$ ventral from the dorsal surface of the skull, $1.0 \mathrm{~mm}$ caudal, and 2.0 lateral. Then, $5 \times 10^{5}$ cells were injected at a depth of $2.2 \mathrm{~mm}$ and the syringe was then retracted to $1.8 \mathrm{~mm}$ and an additional $5 \times 10^{5}$ cells were then administered. To allow for delivery of $\mu \mathrm{CAP}$, an endoscopic tube was then implanted at a depth of $2.2 \mathrm{~mm}$ and secured in place with dental cement. Mice were allowed to recover for 7 days and He $\mu$ CAP or vehicle control (He alone) was then administered. In brief, mice were anesthetized with isofluorane and CAP was applied via the implanted endoscopic tube at 5-s intervals, followed by $15 \mathrm{~s}$ off, for a total CAP treatment time of $15 \mathrm{~s}$. The jet was removed from the endoscopic tube to allow for venting of He. Tumor size was estimated using in vivo bioluminescent imaging before and for up to $48 \mathrm{~h}$ post CAP or vehicle treatment. For bioluminescent imaging, animals were anesthetized with isoflurane and the substrate luciferin was administered i.p., (150 mg/kg). The mice were then transferred to the light-sealed imaging cabinet of an IVIS Lumina $\mathrm{K}$ machine and positioned in a nose cone in order to maintain anesthesia. Bioluminescent images were acquired using a charge-coupled device camera cooled to $-80{ }^{\circ} \mathrm{C}$ to achieve maximal sensitivity. Images were acquired at $10 \mathrm{~min}$ post substrate injection with an exposure time of $20 \mathrm{~s}$, medium binning, F/Stop =1, and EM gain off.

\subsection{Definition of Control}

In Figures 4 and 6, there are " $0 \mathrm{~s}$ " treatments, which represent no $\mu$ CAP treatment used as control.

\subsection{Statistical Analysis}

Results were plotted using Origin 8 as mean \pm standard deviation. Student $t$-test was used to check the statistical significance $\left({ }^{*} p<0.05,{ }^{* *} p<0.01,{ }^{* * *} p<0.001\right)$.

\section{Conclusions}

In summary, the effect of a newly developed $\mu \mathrm{CAP}$ on glioblastoma both in vitro and in vivo has been demonstrated. A variety of diagnostics tools were applied to the $\mu \mathrm{CAP}$, including optical emission spectroscopy, microwave scattering, and potential measurement, which supplied evidence for reactions of plasma-generated species in media and the mouse brain. The $\mu$ CAP direct treatment has a stronger effect than the indirect treatment due to the synergetic effect of short- and long-lived species, while a strong effect of indirect $\mu$ CAP treatment on cancer cells is likely attributed to the action of long-lived species. The $\mu \mathrm{CAP}$ is safe for mice and suppresses tumor growth in the mouse brain. These initial observations establish $\mu \mathrm{CAP}$ as a potentially useful ablative therapy in glioblastoma.

Acknowledgments: This work was supported in part by The National Science Foundation, grant \#1465061, and the George Washington Institute for Biomedical Engineering Interdisciplinary Research Fund. We thank Ka Bian from the Department of Biochemistry and Molecular Medicine at The George Washington University for support with the experiments for measuring ROS and RNS.

Author Contributions: Zhitong Chen, Hayk Simonyan, Xiaoqian Cheng, Eda Gjika, Li Lin, Jerome Canady, Jonathan H. Sherman, Colin Young, and Michael Keidar contributed to the study design and analysis and the writing of the report. All authors provided approval of the final draft of the report.

Conflicts of Interest: The authors declare no conflict of interest. 


\section{References}

1. Attri, P.; Kumar, N.; Park, J.H.; Yadav, D.K.; Choi, S.; Uhm, H.S.; Kim, I.T.; Choi, E.H.; Lee, W. Influence of reactive species on the modification of biomolecules generated from the soft plasma. Sci. Rep. 2015, 5, 08221. [CrossRef] [PubMed]

2. Ratovitski, E.A.; Cheng, X.; Yan, D.; Sherman, J.H.; Canady, J.; Trink, B.; Keidar, M. Anti-cancer therapies of 21st century: Novel approach to treat human cancers using cold atmospheric plasma. Plasma Process. Polym. 2014, 11, 1128-1137. [CrossRef]

3. Keidar, M.; Beilis, I. Plasma Engineering: Applications from Aerospace to Bio and Nanotechnology; Academic Press: London, UK, 2013.

4. Flynn, P.B.; Busetti, A.; Wielogorska, E.; Chevallier, O.P.; Elliott, C.T.; Laverty, G.; Gorman, S.P.; Graham, W.G.; Gilmore, B.F. Non-thermal Plasma Exposure Rapidly Attenuates Bacterial AHL-Dependent Quorum Sensing and Virulence. Sci. Rep. 2016, 6, 26320. [CrossRef] [PubMed]

5. Keidar, M.; Walk, R.; Shashurin, A.; Srinivasan, P.; Sandler, A.; Dasgupta, S.; Ravi, R.; Guerrero-Preston, R.; Trink, B. Cold plasma selectivity and the possibility of a paradigm shift in cancer therapy. Br. J. Cancer 2011, 105, 1295-1301. [CrossRef] [PubMed]

6. Yousfi, M.; Merbahi, N.; Pathak, A.; Eichwald, O. Low-temperature plasmas at atmospheric pressure: Toward new pharmaceutical treatments in medicine. Fundam. Clin. Pharmacol. 2014, 28, 123-135. [CrossRef] [PubMed]

7. Schmidt, A.; Wende, K.; Bekeschus, S.; Bundscherer, L.; Barton, A.; Ottmüller, K.; Weltmann, K.-D.; Masur, K. Non-thermal plasma treatment is associated with changes in transcriptome of human epithelial skin cells. Free Radic. Res. 2013, 47, 577-592. [CrossRef] [PubMed]

8. Choi, J.W.; Kang, S.U.; Kim, Y.E.; Park, J.K.; Yang, S.S.; Kim, Y.S.; Lee, Y.S.; Lee, Y.; Kim, C.-H. Novel Therapeutic Effects of Non-thermal atmospheric pressure plasma for Muscle Regeneration and Differentiation. Sci. Rep. 2016, 6, 28829. [CrossRef] [PubMed]

9. Daeschlein, G.; Napp, M.; Lutze, S.; Arnold, A.; Podewils, S.; Guembel, D.; Jünger, M. Skin and wound decontamination of multidrug-resistant bacteria by cold atmospheric plasma coagulation. JDDG J. Deutsch. Dermatol. Ges. 2015, 13, 143-149. [CrossRef] [PubMed]

10. Robert, E.; Vandamme, M.; Brullé, L.; Lerondel, S.; le Pape, A.; Sarron, V.; Riès, D.; Darny, T.; Dozias, S.; Collet, G. Perspectives of endoscopic plasma applications. Clin. Plasma Med. 2013, 1, 8-16. [CrossRef]

11. Keidar, M. Plasma for cancer treatment. Plasma Sour. Sci. Technol. 2015, 24, 033001. [CrossRef]

12. Volotskova, O.; Hawley, T.S.; Stepp, M.A.; Keidar, M. Targeting the cancer cell cycle by cold atmospheric plasma. Sci. Rep. 2012, 2, 00636. [CrossRef] [PubMed]

13. Kirson, E.D.; Dbalý, V.; Tovaryš, F.; Vymazal, J.; Soustiel, J.F.; Itzhaki, A.; Mordechovich, D.; Steinberg-Shapira, S.; Gurvich, Z.; Schneiderman, R. Alternating electric fields arrest cell proliferation in animal tumor models and human brain tumors. Proc. Natl. Acad. Sci. USA 2007, 104, 10152-10157. [CrossRef] [PubMed]

14. Chen, Z.; Lin, L.; Cheng, X.; Gjika, E.; Keidar, M. Effects of cold atmospheric plasma generated in deionized water in cell cancer therapy. Plasma Process. Polym. 2016, 13, 1151-1156. [CrossRef]

15. Keidar, M.; Shashurin, A.; Volotskova, O.; Stepp, M.A.; Srinivasan, P.; Sandler, A.; Trink, B. Cold atmospheric plasma in cancer therapya. Phys. Plasmas (1994-present) 2013, 20, 057101. [CrossRef]

16. Fridman, G.; Friedman, G.; Gutsol, A.; Shekhter, A.B.; Vasilets, V.N.; Fridman, A. Applied plasma medicine. Plasma Process. Polym. 2008, 5, 503-533. [CrossRef]

17. Dikalov, S.I.; Harrison, D.G. Methods for detection of mitochondrial and cellular reactive oxygen species. Antioxid. Redox Signal. 2014, 20, 372-382. [CrossRef] [PubMed]

18. Leduc, M.; Guay, D.; Coulombe, S.; Leask, R.L. Effects of Non-thermal Plasmas on DNA and Mammalian Cells. Plasma Process. Polym. 2010, 7, 899-909. [CrossRef]

19. Kalghatgi, S.; Friedman, G.; Fridman, A.; Clyne, A.M. Endothelial cell proliferation is enhanced by low dose non-thermal plasma through fibroblast growth factor-2 release. Ann. Biomed. Eng. 2010, 38, 748-757. [CrossRef] [PubMed]

20. Joh, H.M.; Kim, S.J.; Chung, T.; Leem, S. Reactive oxygen species-related plasma effects on the apoptosis of human bladder cancer cells in atmospheric pressure pulsed plasma jets. Appl. Phys. Lett. 2012, 101, 053703. 
21. Shashurin, A.; Keidar, M.; Bronnikov, S.; Jurjus, R.; Stepp, M. Living tissue under treatment of cold plasma atmospheric jet. Appl. Phys. Lett. 2008, 93, 181501. [CrossRef]

22. Iseki, S.; Nakamura, K.; Hayashi, M.; Tanaka, H.; Kondo, H.; Kajiyama, H.; Kano, H.; Kikkawa, F.; Hori, M. Selective killing of ovarian cancer cells through induction of apoptosis by nonequilibrium atmospheric pressure plasma. Appl. Phys. Lett. 2012, 100, 113702. [CrossRef]

23. Gweon, B.; Kim, M.; Kim, D.B.; Kim, D.; Kim, H.; Jung, H.; Shin, J.H.; Choe, W. Differential responses of human liver cancer and normal cells to atmospheric pressure plasma. Appl. Phys. Lett. 2011, 99, 063701. [CrossRef]

24. Zucker, S.N.; Zirnheld, J.; Bagati, A.; DiSanto, T.M.; Soye, B.D.; Wawrzyniak, J.A.; Etemadi, K.; Nikiforov, M.; Berezney, R. Preferential induction of apoptotic cell death in melanoma cells as compared with normal keratinocytes using a non-thermal plasma torch. Cancer Biol. Ther. 2012, 13, 1299-1306. [CrossRef] [PubMed]

25. Kolb, J.F.; Mohamed, A.-A.H.; Price, R.; Swanson, R.; Bowman, A.; Chiavarini, R.; Stacey, M.; Schoenbach, K. Cold atmospheric pressure air plasma jet for medical applications. Appl. Phys. Lett. 2008, 92, 241501. [CrossRef]

26. Kalghatgi, S.U.; Fridman, G.; Cooper, M.; Nagaraj, G.; Peddinghaus, M.; Balasubramanian, M.; Vasilets, V.N.; Gutsol, A.F.; Fridman, A.; Friedman, G. Mechanism of blood coagulation by nonthermal atmospheric pressure dielectric barrier discharge plasma. IEEE Trans. Plasma Sci. 2007, 35, 1559-1566. [CrossRef]

27. Bussiahn, R.; Brandenburg, R.; Gerling, T.; Kindel, E.; Lange, H.; Lembke, N.; Weltmann, K.-D.; von Woedtke, T.; Kocher, T. The hairline plasma: An intermittent negative dc-corona discharge at atmospheric pressure for plasma medical applications. Appl. Phys. Lett. 2010, 96, 143701. [CrossRef]

28. Mutaf-Yardimci, O.; Saveliev, A.V.; Fridman, A.A.; Kennedy, L.A. Thermal and nonthermal regimes of gliding arc discharge in air flow. J. Appl. Phys. 2000, 87, 1632-1641. [CrossRef]

29. Mirpour, S.; Piroozmand, S.; Soleimani, N.; Faharani, N.J.; Ghomi, H.; Eskandari, H.F.; Sharifi, A.M.; Mirpour, S.; Eftekhari, M.; Nikkhah, M. Utilizing the micron sized non-thermal atmospheric pressure plasma inside the animal body for the tumor treatment application. Sci. Rep. 2016, 6, 29048. [CrossRef] [PubMed]

30. Kim, J.Y.; Wei, Y.; Li, J.; Foy, P.; Hawkins, T.; Ballato, J.; Kim, S.O. Single-cell-level microplasma cancer therapy. Small 2011, 7, 2291-2295. [CrossRef] [PubMed]

31. Tan, X.; Zhao, S.; Lei, Q.; Lu, X.; He, G.; Ostrikov, K. Single-cell-precision microplasma-induced cancer cell apoptosis. PLoS ONE 2014, 9, e101299. [CrossRef] [PubMed]

32. Thomas, A.A.; Brennan, C.W.; DeAngelis, L.M.; Omuro, A.M. Emerging therapies for glioblastoma. JAMA Neurol. 2014, 71, 1437-1444. [CrossRef] [PubMed]

33. Ostrom, Q.T.; Gittleman, H.; Fulop, J.; Liu, M.; Blanda, R.; Kromer, C.; Wolinsky, Y.; Kruchko, C.; Barnholtz-Sloan, J.S. CBTRUS Statistical Report: Primary Brain and Central Nervous System Tumors Diagnosed in the United States in 2008-2012; Neuro-oncology: London, UK, 2015; Volume 17 (Suppl. 4); pp. iv1-iv62.

34. Tan, Q.; Saggar, J.K.; Yu, M.; Wang, M.; Tannock, I.F. Mechanisms of drug resistance related to the microenvironment of solid tumors and possible strategies to inhibit them. Cancer J. 2015, 21, 254-262. [CrossRef] [PubMed]

35. Pearse, R.W.B.; Gaydon, A.G.; Pearse, R.W.B.; Gaydon, A.G. The Identification of Molecular Spectra; Chapman and Hall: London, UK, 1976.

36. Shashurin, A.; Shneider, M.; Dogariu, A.; Miles, R.; Keidar, M. Temporary-resolved measurement of electron density in small atmospheric plasmas. Appl. Phys. Lett. 2010, 96, 171502. [CrossRef]

37. Lin, L.; Keidar, M. Cold atmospheric plasma jet in an axial DC electric field. Phys. Plasmas (1994-Present) 2016, 23, 083529. [CrossRef]

38. Popov, N. Associative ionization reactions involving excited atoms in nitrogen plasma. Plasma Phys. Rep. 2009, 35, 436-449. [CrossRef]

39. Chen, Z.; Lin, L.; Cheng, X.; Gjika, E.; Keidar, M. Treatment of gastric cancer cells with nonthermal atmospheric plasma generated in water. Biointerphases 2016, 11, 031010. [CrossRef] [PubMed]

40. Chen, Z.; Cheng, X.; Lin, L.; Keidar, M. Cold atmospheric plasma discharged in water and its potential use in cancer therapy. J. Phys. D Appl. Phys. 2017, 50, 015208. [CrossRef]

41. Satoh, A.Y.; Trosko, J.E.; Masten, S.J. Methylene blue dye test for rapid qualitative detection of hydroxyl radicals formed in a Fenton's reaction aqueous solution. Environ. Sci. Technol. 2007, 41, 2881-2887. [CrossRef] [PubMed] 
42. Locke, B.R.; Thagard, S.M. Analysis and review of chemical reactions and transport processes in pulsed electrical discharge plasma formed directly in liquid water. Plasma Chem. Plasma Process. 2012, 32, 875-917. [CrossRef]

43. Attri, P.; Sarinont, T.; Kim, M.; Amano, T.; Koga, K.; Cho, A.E.; Choi, E.H.; Shiratani, M. Influence of ionic liquid and ionic salt on protein against the reactive species generated using dielectric barrier discharge plasma. Sci. Rep. 2015, 5, 17781. [CrossRef] [PubMed]

44. Mirpour, S.; Ghomi, H.; Piroozmand, S.; Nikkhah, M.; Tavassoli, S.H.; Azad, S.Z. The selective characterization of nonthermal atmospheric pressure plasma jet on treatment of human breast cancer and normal cells. IEEE Trans. Plasma Sci. 2014, 42, 315-322. [CrossRef]

45. Yan, D.; Talbot, A.; Nourmohammadi, N.; Cheng, X.; Canady, J.; Sherman, J.; Keidar, M. Principles of using cold atmospheric plasma stimulated media for cancer treatment. Sci. Rep. 2015, 5, 18339. [CrossRef] [PubMed]

46. Winter, J.; Tresp, H.; Hammer, M.; Iseni, S.; Kupsch, S.; Schmidt-Bleker, A.; Wende, K.; Dünnbier, M.; Masur, K.; Weltmann, K. Tracking plasma generated $\mathrm{H}_{2} \mathrm{O}_{2}$ from gas into liquid phase and revealing its dominant impact on human skin cells. J. Phys. D Appl. Phys. 2014, 47, 285401. [CrossRef]

47. Graves, D.B. The emerging role of reactive oxygen and nitrogen species in redox biology and some implications for plasma applications to medicine and biology. J. Phys. D Appl. Phys. 2012, 45, 263001. [CrossRef]

48. Tian, W.; Kushner, M.J. Atmospheric pressure dielectric barrier discharges interacting with liquid covered tissue. J. Phys. D Appl. Phys. 2014, 47, 165201. [CrossRef]

49. Boehm, D.; Heslin, C.; Cullen, P.J.; Bourke, P. Cytotoxic and mutagenic potential of solutions exposed to cold atmospheric plasma. Sci. Rep. 2016, 6, 21464. [CrossRef] [PubMed]

50. Kim, S.J.; Chung, T. Cold atmospheric plasma jet-generated RONS and their selective effects on normal and carcinoma cells. Sci. Rep. 2016, 6, 20332. [CrossRef] [PubMed]

51. Lukes, P.; Dolezalova, E.; Sisrova, I.; Clupek, M. Aqueous-phase chemistry and bactericidal effects from an air discharge plasma in contact with water: Evidence for the formation of peroxynitrite through a pseudo-second-order post-discharge reaction of $\mathrm{H}_{2} \mathrm{O}_{2}$ and $\mathrm{HNO}_{2}$. Plasma Sour. Sci. Technol. 2014, 23, 015019. [CrossRef]

52. Kurake, N.; Tanaka, H.; Ishikawa, K.; Kondo, T.; Sekine, M.; Nakamura, K.; Kajiyama, H.; Kikkawa, F.; Mizuno, M.; Hori, M. Cell survival of glioblastoma grown in medium containing hydrogen peroxide and/or nitrite, or in plasma-activated medium. Arch. Biochem. Biophys. 2016, 605, 102-108. [CrossRef] [PubMed]

53. Bienert, G.P.; Chaumont, F. Aquaporin-facilitated transmembrane diffusion of hydrogen peroxide. Biochim. Biophys. Acta (BBA)-Gen. Subj. 2014, 1840, 1596-1604. [CrossRef] [PubMed]

54. Ishibashi, K.; Hara, S.; Kondo, S. Aquaporin water channels in mammals. Clin. Exp. Nephrol. 2009, 13, 107-117. [CrossRef] [PubMed]

55. Yan, D.; Talbot, A.; Nourmohammadi, N.; Sherman, J.H.; Cheng, X.; Keidar, M. Toward understanding the selective anticancer capacity of cold atmospheric plasma-A model based on aquaporins (Review). Biointerphases 2015, 10, 040801. [CrossRef] [PubMed]

56. Papadopoulos, M.C.; Saadoun, S. Key roles of aquaporins in tumor biology. Biochim. Biophys. Acta (BBA)-Biomembr. 2015, 1848, 2576-2583. [CrossRef] [PubMed]

57. Dobrynin, D.; Fridman, G.; Friedman, G.; Fridman, A. Physical and biological mechanisms of direct plasma interaction with living tissue. New J. Phys. 2009, 11, 115020. [CrossRef]

58. Gebicki, S.; Gebicki, J.M. Crosslinking of DNA and proteins induced by protein hydroperoxides. Biochem. J. 1999, 338, 629-636. [CrossRef] [PubMed]

59. Adachi, T.; Tanaka, H.; Nonomura, S.; Hara, H.; Kondo, S.; Hori, M. Plasma-activated medium induces A549 cell injury via a spiral apoptotic cascade involving the mitochondrial-nuclear network. Free Radic. Biol. Med. 2015, 79, 28-44. [CrossRef] [PubMed]

60. Fridman, A.; Chirokov, A.; Gutsol, A. Non-thermal atmospheric pressure discharges. J. Phys. D Appl. Phys. 2005, 38, R1-R24. [CrossRef]

61. Takamatsu, T.; Uehara, K.; Sasaki, Y.; Miyahara, H.; Matsumura, Y.; Iwasawa, A.; Ito, N.; Azuma, T.; Kohno, M.; Okino, A. Investigation of reactive species using various gas plasmas. RSC Adv. 2014, 4, 39901-39905. [CrossRef] 
62. Kaushik, N.; Uddin, N.; Sim, G.B.; Hong, Y.J.; Baik, K.Y.; Kim, C.H.; Lee, S.J.; Kaushik, N.K.; Choi, E.H. Responses of solid tumor cells in DMEM to reactive oxygen species generated by non-thermal plasma and chemically induced ROS systems. Sci. Rep. 2015, 5, 08587. [CrossRef] [PubMed]

63. Walsh, J.L.; Kong, M.G. Contrasting characteristics of linear-field and cross-field atmospheric plasma jets. Appl. Phys. Lett. 2008, 93, 111501. [CrossRef]

64. Kos, S.; Blagus, T.; Cemazar, M.; Filipic, G.; Sersa, G.; Cvelbar, U. Safety aspects of atmospheric pressure helium plasma jet operation on skin: In vivo study on mouse skin. PLoS ONE 2017, 12, e0174966.

65. Riedl, S.J.; Shi, Y. Molecular mechanisms of caspase regulation during apoptosis. Nat. Rev. Mol. Cell Biol. 2004, 5, 897-907. [CrossRef] [PubMed]

66. Schweitzer, C.; Schmidt, R. Physical mechanisms of generation and deactivation of singlet oxygen. Chem. Rev. 2003, 103, 1685-1758. [CrossRef] [PubMed]

67. Dougherty, T.J.; Gomer, C.J.; Henderson, B.W.; Jori, G.; Kessel, D.; Korbelik, M.; Moan, J.; Peng, Q. Photodynamic therapy. J. Natl. Cancer Inst. 1998, 90, 889-905. [CrossRef] [PubMed]

68. Pacher, P.; Beckman, J.S.; Liaudet, L. Nitric oxide and peroxynitrite in health and disease. Physiol. Rev. 2007, 87, 315-424. [CrossRef] [PubMed]

69. Cheng, X.; Sherman, J.; Murphy, W.; Ratovitski, E.; Canady, J.; Keidar, M. The effect of tuning cold plasma composition on glioblastoma cell viability. PLoS ONE 2014, 9, e98652. [CrossRef] [PubMed]

(c) 2017 by the authors. Licensee MDPI, Basel, Switzerland. This article is an open access article distributed under the terms and conditions of the Creative Commons Attribution (CC BY) license (http://creativecommons.org/licenses/by/4.0/). 